\title{
Impact of Mulch on Water Loss from a Container Substrate and Native Soil
}

\author{
Edward F. Gilman, Richard C. Beeson, and Dustin Meador
}

\begin{abstract}
This study was designed to measure evaporation from substrate-filled and soil-filled containers $(360 \mathrm{~L})$ to simulate a planted root ball. There was no difference in evaporation between mulched and non-mulched soil-filled lysimeters in any consecutive three-day period following irrigation. In contrast, more evaporation occurred the first dry day after irrigation from substrate-filled lysimeters covered with mulch than from those without mulch. Non-mulched substrate-filled lysimeters lost more water to evaporation than mulched lysimeters in the second day after irrigation. Cumulative evaporation through day two was identical for mulched and non-mulched substrate treatments. Cumulative evaporation through the third dry day, after irrigation, was $0.5 \mathrm{~L}$ greater from non-mulched lysimeters because of higher evaporation. Mulched or not, only about one liter evaporated daily from the surface of the substrate-filled or soil-filled lysimeters during consecutive, three-day rain-free periods following irrigation. Evaporation accounted for an estimated $4 \%$ of water loss from the root ball the first three days following irrigation; based on similar studies with trees present, the remaining $96 \%$ would have been lost through transpiration. Given minor reduction in evaporation, and reported disadvantages of mulch application close to the trunk, landscape managers might consider changing mulch application practices for newly planted trees.

Key Words. Evaporation; Irrigation; Lysimeters; Transplanting.
\end{abstract}

There is ample evidence that application of organic-based mulches to the surface of many soils reduces evaporation, increases organic matter, and changes other soil properties (Chalker-Scott 2007; Dahiya et al. 2007; Demir et al. 2009). Unger and Parker (1976) also reported a decreased evaporation rate for mulched plots, but only for approximately 15 days after water was applied. After that point, cumulative evaporation rates were not significantly different or were greater in mulched plots than bare soil plots. As a result of enhanced moisture in the root zone and other soil changes, mulch generally aids germination of tree seeds and the establishment of very young bare root and containergrown tree seedlings and saplings less than $1.7 \mathrm{~m}$ tall at planting (Chalker-Scott 2007), although there are examples where mulch application was of no benefit to growth (Sun et al. 1994; Erhart and Hartl 2003). Some studies show no organic mulch impact on sapling survival for certain species and enhanced survival on others (Barajas-Guzman et al. 2006). Enhanced survival and establishment of seeds and saplings, brought about by mulchinduced water retention, is especially relevant on adverse sites such as mine tailings (Munir et al. 1998), restoration sites and saline soils, and in subarctic conditions (Houle and Babeux 1994).

Although applying mulch to the top of the root ball and surrounding soil of newly planted landscape trees is standard practice in many regions (Watson and Himelick 1998), there is much less research on mulch application strategies for landscape-sized trees, and almost none on landscape-sized trees planted from containers. Mulch applied at planting results in fewer weeds around the trunk compared to non-mulched trees planted into a landscape, with thicker layers resulting in fewer weeds (Skroch et al.
1992; Greenly and Rakow 1995). However mulch does not eliminate weeds (Asworth and Harrison 1983), thus herbicide applications or other methods of weed control are necessary in many instances (Arnold and McDonald 2008). Elimination of weeds from the root ball reduces competition for available soil water.

Although mulch applied around the root ball when planting into the landscape appears to consistently moderate soil properties such as temperature and moisture measured outside the root ball (Scharenbroch 2009), mulch has not been consistently associated with enhanced establishment of newly planted landscape-sized trees. A review of existing literature did not reveal any studies showing increased survival rates resulting from applications of mulch; however, mulch on the root ball surface and on the surrounding soil has been associated with reduced survival or post-planting growth (Hensley et al. 1988; Hild and Morgan 1993; Arnold 2005; Singer and Martin 2009). Five studies showed a slight increase in growth for some of the species tested (Litzow and Pellett 1983; Smith et al. 2000; Montague et al. 2007; Ferrini et al. 2008; Arnold and McDonald 2009). In many studies, trees and palms planted in mulched landscape soil in different climates responded identically to those surrounded by bare soil, suggesting little benefit to water relations within the root ball from mulch application (Kraus 1998; Downer and Hodel 2001; Gilman and Grabosky 2004; Bryan et al. 2008; Singer and Martin 2009). Scharenbroch (2009) also concluded from a meta-analysis of published data that organic mulch applied on and/or around the root ball had no positive impact on tree health.

Other potential drawbacks to placing mulch on the root ball and against the trunk include increased rodent damage (Pruett 1959), 
termite infestations (pers. obs.: R.C. Beeson), slow soil warming in spring (Litzow and Pellett 1983), retaining and/or repelling water (Gilman and Grabosky 2004), and girdling root formation (Johnson and Hauer 2000). Lenticel size also increased when mulch rested against the trunk for 17 months after planting, perhaps to compensate for lowered oxygen levels (Greenly and Rakow 1995).

There is little data describing mulch impacts on direct measurements of moisture relations within the root ball (Altland and Lanthier 2007) after planting. The importance of water status within the root ball is obvious because it is more important to tree survival in the weeks and months following planting than moisture in the surrounding landscape soil (Watson and Kupkowski 1991b).

With questionable benefits of mulch to survival, growth, and health of newly planted landscape-sized trees under experimental conditions, combined with the potential disadvantages of mulch applied to the root ball surface, this study was designed to evaluate if application of mulch over the root ball surface impacts evaporation. The hypothesis was that mulch placed on the root ball surface had negligible impact on evaporative water loss. Aboveground lysimeters were designed to eliminate perched water tables in order to simulate root balls planted into landscape soils. This allowed for gravimetric measurement of water loss from the root ball with and without pine bark mulch. No trees were in the lysimeters.

\section{MATERIALS AND METHODS}

\section{Lysimeter Construction}

Lysimeters are non-porous containers made from plastic or other materials that can be positioned above or in the ground to simulate plant water usage in the landscape (Pearson and Scheiber 2006). The authors of the current study used $360 \mathrm{~L}(105 \mathrm{~cm}$ top diameter $\times 49 \mathrm{~cm}$ tall) black plastic containers common in the nursery trade. Sides of containers were covered with aluminum foil to reflect heat to better simulate a substrate or soil root ball planted in the ground. These lysimeters were placed above ground on platforms of industrial steel shelving measuring 109 $\mathrm{cm} \times 117 \mathrm{~cm}$ resting on two $5 \mathrm{~cm} \times 150 \mathrm{~cm}$ long, $6 \mathrm{~mm}$ thick, angle-irons. Four $\mathrm{cm}$ from the ends of the angle iron, about $45 \mathrm{~cm}$ of $7 \mathrm{~mm}$ thick chain (580 kg working load limit) was bolted to the angle iron forming a loop. These were used as lifting points to weigh the lysimeters and platforms together. Bricks were used as footings for angle irons to provide a level platform approximately $10 \mathrm{~cm}$ above the soil surface. Platforms were stiff enough to prevent lysimeter deformation when lifting the platform.

A system was devised to eliminate the perched water table that occurs in a container (Richards et al. 1986; Bilderback and Fonteno 1987; Spooner 1974) by wicking water into the landscape soil beneath the lysimeter. This allowed for a better simulation of water drainage from a root ball planted into the landscape. A single layer of Aquamat (Soleno Textiles, Laval, Quebec, Canada) capillary mat fabric was cut to fit neatly across the bottom and $10 \mathrm{~cm}$ up the container sides to cover all drainage holes previously drilled into the bottom and sides by the manufacturer. A slit was cut through fabric at the position of all nine drainage holes on the bottom surface of the container. A piece of the same fabric $(76 \mathrm{~cm}$ long $\times 2.5 \mathrm{~cm}$ wide) was pushed through the slit and out each drainage hole. Fifteen $\mathrm{cm}$ of the fabric wick rested on the fabric mat at the container bottom with the other end of each wick resting on bare landscape soil below the lysimeter. When a lysimeter received water, it drained out the holes wicking through the fabric and into landscape soil below.

\section{Filling Lysimeters}

Each lysimeter for the container root ball test in Spring 2007 was loosely filled (no packing) with $120 \mathrm{~kg}$ of substrate $(60$ composted pine bark:30 Florida peat:10 sand by volume, Florida Potting Soil, Inc., Orlando, Florida, U.S.) that was typical for a container nursery in southeastern United States. In autumn 2007, the substrate was replaced with $351 \mathrm{~kg}$ of native sand soil (Millhopper fine sand; loamy, siliceous, hyperthermic Grossarenic Paleudults) with less than $2 \%$ organic matter) for the field-grown root ball test. Either substrate or soil filled the container to $10 \mathrm{~cm}$ from the top. This system simulated planting a $360 \mathrm{~L}$ container or a field-grown root ball one meter in diameter into the landscape. Spring and autumn were chosen because weather in the state of Florida is similarly warm with infrequent rainfall. Periods of consecutive rain-free days were needed to conduct the study.

Twenty-two lysimeters on platforms in full sun were placed $2 \mathrm{~m}$ apart in two rows. Treatments, mulched and non-mulched, were assigned at random to 18 uncovered lysimeters. After filling with substrate or soil, nine lysimeters received no mulch and nine received an 8-cm-thick layer $(85.2 \mathrm{~L}$ ) of large-particle (up to $8 \mathrm{~cm}$ long) non-composted pine bark as mulch. Pine bark was placed on a $25 \mathrm{~mm}$ sieve screen and gently shaken five times prior to application in an effort to standardize particle size distribution in each mulched lysimeter. The particles that remained in the screen were applied to the surface. Sides of non-mulched lysimeters were shortened by $8 \mathrm{~cm}$ so the distance between the top surface of mulch or substrate to the top of lysimeters was equal $(5 \mathrm{~cm})$. This eliminated differential shading of the lysimeter surface. Four lysimeters were permanently covered with the plastic sheet described below except to facilitate irrigation when all 22 lysimeters received water.

\section{Measuring Evaporation}

In April 2007, substrate in four lysimeters was thoroughly wetted with five applications of $57 \mathrm{~L}$ of water spaced about 1.5 hours apart for two consecutive days. Water was applied uniformly using a handheld nozzle attached to a hose. After the last application, each lysimeter was covered with $6 \mathrm{~mm}$ white polyvinyl sheets attached to the top sides of the lysimeter with 12 clips. Each lysimeter was then weighed 30 minutes after the last irrigation that afternoon, and again at 10:00 am the following morning to evaluate the consistency of substrate saturation and drainage. This was repeated twice more within two weeks. Lysimeters, consisting of the steel platform and containers, were weighed together with one in-line $909 \mathrm{~kg}$ capacity load cell (SSM-AF-2000; Interface Inc. Scottsdale, Arizona, U.S.) suspended from a chain held up by a frontend loader mounted on a medium-size tractor. The same protocol preceded the soil root ball test conducted in October 2007.

On May 2 and 3, 2007, saturation procedure previously described was repeated on all 22 lysimeters, with an additional three applications on May 4 for a total of 738 L. Water drained out the bottom of lysimeters at every application on May 3 and 4. All 22 lysimeters then received $60 \mathrm{~L}$ water as described from 3:00 pm to 4:00 pm on all irrigation days beginning May 7, 2007, for the substrate test. Covered lysimeters were re-covered immediately after each application. Lysimeters were weighed 60 
minutes following irrigation in the same order as water was applied (4:00 pm to 5:00 pm the same day) so the time between watering and weighing was identical (60 minutes) for all lysimeters. Lysimeters were reweighed in the same order 22 hours later (2:00 pm to $3: 00 \mathrm{pm})$ when most gravitational water had drained; this weight was considered the start weight for day one. Lysimeters were reweighed $24,48,72,96$, and 120 hours later in the same order 2:00 pm to $3: 00 \mathrm{pm}$ in absence of rainfall. Difference between start weight and weight on each of these days represented 24-hour water loss for days one, two, three, four, and five, respectively. When rainfall interrupted the rain-free dry-down period, $60 \mathrm{~L}$ irrigation was re-applied at 3:00 pm that day or the following day and the dry-down period started over. The study was concluded June 18 when frequent rainfall did not allow for more than a few consecutive rain-free days. Four three-day dry-down periods (for soil and substrate), and one five-day dry down period (for soil) from May 7 through June 18, 2007 were recorded.

Weight loss from the four covered lysimeters represented the amount of water lost by wicking through capillary mat fabric into landscape soil under the platform; weight loss from the 18 uncovered lysimeters represented wicked water plus evaporation from the surface. Thus, evaporation from the 18 uncovered lysimeters was calculated by subtracting mean wicked weight loss from the four covered lysimeters for the same time period from weight loss in each of the 18 uncovered lysimeters. Total water loss and calculated evaporation was reported as a mean for mulched and non-mulched lysimeters.

The field soil test was performed September 14 through November 2, 2007. Soil was mixed with a backhoe prior to filling lysimeters to provide uniformity among lysimeters. The same protocols described for the container substrate test were used. Like the substrate test, there were four complete, three-day dry-down periods.

\section{Statistical Analysis}

The GLM procedure with repeated measurement analysis in SAS was used to perform a completely randomized one-way analysis of variance in a randomized block design (using each of the four, three-day dry-down periods as a block). Evaporation from mulched versus non-mulched lysimeters was compared independently for the first (Day 1), second (Day 2), and third (Day 3) dry day after irrigation. There were nine lysimeters mulched and nine not mulched within each block. The single four-day and five-day dry-down periods were analyzed as a completely randomized one-way analysis of variance with nine lysimeters per treatment. Means were compared using Duncan's multiple range test with $P<0.05$. The spring 2007 container substrate test was analyzed separately from the autumn 2007 native soil test.

\section{RESULTS AND DISCUSSION}

Testing several days prior to the study in May (spring) 2007 showed that temperature over the course of several sunny days in two container substrate plugs of identical shape and volume as the $360 \mathrm{~L}$ containers installed in adjacent landscape soil was within one degree Celsius of that inside the aluminum foil covered $360 \mathrm{~L}$ containers (data not shown). The three-day irrigation protocol on the four $360 \mathrm{~L}$ covered lysimeters filled with substrate conducted three times over a two-week period mid to late April 2007 resulted in consistent weight gain 30 minutes following irrigation in late afternoon of the second day, and consistent weight loss overnight through 10:00 am the following morning within $+/-1.0 \%$ (data not shown). With uniform weight gain and loss attributes following irrigation in this manner, dry pockets should be eliminated from the substrate. The same protocol preceded the native soil test conducted in October (autumn) 2007 and resulted in consistent weight gain and loss attributes as described for container substrate within $+/-1.0 \%$.

There was no difference in evaporation between mulched and non-mulched lysimeters filled with native sandy soil in each of the first three days after irrigation as averaged across four dry-down periods (Table 1), nor was there a difference in the one five-day dry-down period (data not shown). Soilfilled lysimeters without mulch had greater $(0.5 \mathrm{~L})$ cumulative (Day $1+$ Day 2) evaporation at the end of the second day, but there was no statistical difference three days after irrigation.

More evaporation occurred from substrate-filled lysimeters with mulch than those without mulch the first dry day after irrigation (Table 1). Most likely, some of the applied water was retained in the mulch sitting on top of substrate as suggested in a study that included trees in landscape soil (Gilman and Grabosky 2004). Partial vapor pressure of water in mulch would have been less than in substrate because of the much larger pores in the mulch layer. This would have driven more water into the vapor phase in mulch than from the non-mulched substrate resulting in greater evaporation. The results here substantiate that trees became more water stressed in that study (Gilman and Grabosky 2004) due to mulch over the root ball intercepting irrigation and rainfall.

Substrate-filled lysimeters without mulch lost more water to evaporation than mulched lysimeters the second day after irrigation. Water loss from these non-mulched lysimeters was con-

Table 1. Daily water loss and daily evaporation from mulched and non-mulched $360 \mathrm{~L}$ lysimeters filled with substrate or soil following application of $60 \mathrm{~L}$ irrigation at day zero.

\begin{tabular}{|c|c|c|c|}
\hline \multirow[t]{2}{*}{ Lysimeter contents/surface treatment } & \multicolumn{3}{|c|}{ Daily water loss and (daily evaporation) in liters } \\
\hline & Day 1 & Day 2 & Day 3 \\
\hline \multicolumn{4}{|l|}{ Substrate-filled ${ }^{\mathrm{z}}$} \\
\hline Mulched surface & $18.5(2.0)^{y} a^{x}$ & $2.0(0.5) b$ & $1.0(0.5) b$ \\
\hline \multicolumn{4}{|l|}{ Soil-filled $^{\mathrm{z}}$} \\
\hline Mulched surface & $21.0(0.5) \mathrm{a}$ & $3.0(1.0) \mathrm{a}$ & $2.0(0.5) \mathrm{a}$ \\
\hline Non-mulched surface & $21.5(1.0) \mathrm{a}$ & $3.5(1.5) \mathrm{a}$ & $2.0(0.5) \mathrm{a}$ \\
\hline
\end{tabular}

${ }^{2}$ Substrate = bark:peat:sand substrate used in nursery containers, study conducted spring 2007; soil = fine sand native soil, study conducted autumn 2007 .

${ }^{y}$ Daily evaporation (in parentheses) calculated as daily water loss from open lysimeters minus mean daily water loss from four covered control lysimeters.

${ }^{x}$ Daily evaporation means, within a lysimeter content, in a column with a different letter are statistically different at $P<0.05$. Means based on nine replication lysimeters averaged across four dry-down period blocks. 
sistent at one liter per day, while lysimeters with mulch was consistent at $0.5 \mathrm{~L}$ per day after the first day (Table 1 ). The net cumulative evaporation through Day 2 was not statistically different between mulched and non-mulched treatments (Table 1). Cumulative evaporation through the third dry day after irrigation was $0.5 \mathrm{~L}$ greater from non-mulched $360 \mathrm{~L}$ lysimeters.

Mulched or not, only about one liter (range 0.5 to $2.0 \mathrm{~L}$, depending on the day) evaporated daily from the surface of the container substrate- or native soil-filled lysimeters in each of the first three days after irrigation. However, water loss from drainage and transpiration, if trees had been growing in the lysimeters, by the end of the first day after irrigation would have required replacement irrigation or substantial rainfall to maintain tree vigor comparable to that at transplanting (Gilman et al. 1998). An $8 \mathrm{~cm}$ caliper maple would transpire about $28 \mathrm{~L}$ per day under non-stressed conditions during the late spring and early autumn in USDA Hardiness Zone 9 when this experiment was conducted (Beeson and Brooks 2008). In addition, irrigation needs of container-grown trees often increase after planting to the landscape compared to needs in the nursery because the perched water table is eliminated when the container is removed and the tree is planted (Gilman et al. 1996; Beeson and Brooks 2008). In Florida, recently-planted trees could become fatally water stressed by the third or fourth day without irrigation (Gilman 2001). Since about one liter evaporated (Table 1) and an average of about $28 \mathrm{~L}$ could have transpired if a tree was present (Beeson and Brooks 2008), the vast majority $(96 \%)$ of water would have left the root ball of a well-irrigated tree in a given day by transpiration, not evaporation. Medina et al. (2005) found similar results for ten tree species grown in containers in Ohio, U.S. Comparable evapotranspiration to Beeson and Brooks (2008) was reported for five tree species of similar size in a different climate (Edwards 1986; Steinberg et al. 1990). Even if mulch could prevent all evaporation from the root ball, evaporated volume appears negligible compared to the volume transpired, and is unlikely to the impact irrigation frequency or volume required to maintain tree vigor and health after planting. Altland and Lanthier (2007) also showed that organic mulch applied to the surface of small $(3 \mathrm{~L}, 15 \mathrm{~cm} \times 15 \mathrm{~cm})$ containers with Hydrangea macrophylla Thunb. had little or no influence on evaporation.

Gilman and Grabosky (2004) demonstrated that some of the negative impacts of mulch application could be attributed to interception of irrigation and rainfall by mulch placed on top of the root ball resulting in tree water stress from a dry root ball. Others have also observed more water stress in mulched trees of certain species in field studies (Arnold 2005). This phenomenon was confirmed by the increased evaporation from mulch-covered lysimeters (Table 1) compared to non-mulched the first day following irrigation. This may have caused at least some of the reduced survival and growth rates in mulched plots of the cited studies. Watson and Kupkowski (1991a) also showed that roots readily grow up into mulch applied over an existing root system. This upward root growth could encourage formation of stem girdling roots on young recently planted trees and might have contributed to the death of Prunus trees from stem girdling roots in the longest study of its kind described by Wells et al. (2006).

This study showed that application of mulch only resulted in about one liter less evaporation from the surface of a $360 \mathrm{~L}$ plug of soil or container substrate over a three-day period following irrigation. Simple extrapolation from this data suggests that much less would evaporate from a smaller container. Combined with the disadvantages listed above, this makes a case for keeping the root ball surface relatively free of mulch on recently planted trees. Mulch interception of water may be more of a problem with light applications of irrigation or rain than when more volume is applied, and when thick layers of certain mulches that mat together form a barrier impenetrable to water (Gilman and Grabosky 2004). Mulch made of pine needles and perhaps other materials with a low density and a low water-holding capacity may allow for better water infiltration, but this has not been studied.

The lysimeter protocol used in this study was not a real landscape simulation because water was only allowed to drain out the bottom, and no trees were in the lysimeters. Water in a real landscape would have been able to flow horizontally away from the root ball, which may have increased rate of water loss from the root ball and reduced evaporated water volume since the root ball could have drier quicker. The current study probably better simulated a well-drained soil type and might not directly apply in soils with slow percolation rates. The presence of a tree in the lysimeter would have shaded the root ball surface perhaps altering the evaporated: transpired water loss ratio, and the transpirating tree would have more rapidly dried the root ball. Water would have been held more strongly by the soil colloids which would have reduced evaporation. Further studies would need to be conducted to determine if this could have completely eliminated any of the small differences in evaporation between mulched and non-mulched lysimeters.

Acknowledgments: Thanks go to The TREE Fund, GreatSouthernTreeConference.org, and the Florida Nursery Growers and Landscape Association for partial funding.

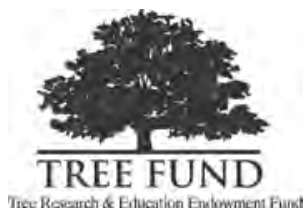

\section{LITERATURE CITED}

Altland, J., and M. Lanthier. 2007. Influence of container mulches on irrigation and nutrient management. Journal of Environmental Horticulture 25:234-238.

Arnold, M.A. 2005. Planting depth and mulch thickness affect establishment of green ash (Fraxinus pennsylvanica) and Bougainvillea goldenraintree (Koelreuteria bipinnata). Journal of Arboriculture 31:163-170.

Arnold, M.A., and G.V. McDonald. 2008. Surface area and method of weed control surrounding green ash trunks affects landscape establishment. Proceedings Southern Nurseryman Association Research Conference 58:391-393.

Arnold, M.A., and G.V. McDonald. 2009. Groundcovers, organic and inorganic mulches, and masonry surfaces differentially affect establishment and root zone characteristics of urban trees. Arboriculture \& Urban Forestry 35:232-240.

Asworth, S., and H. Harrison. 1983. Evaluation of mulches for use in the home garden. HortScience 18:180-182.

Barajas-Guzman, M.G., J. Campo, and V.L. Barradas. 2006. Soil water, nutrient availability and sapling survival under organic and polyethylene mulch in a seasonally dry tropical forest. Plant and Soil 287:347-357.

Beeson, R.C., Jr., and J. Brooks. 2008. Modeling actual evapotranspiration of Acer rubrum from a rooted cutting to an $8 \mathrm{~m}$ tall tree. Acta Horticulture 792:91-97. 
Bilderback, T.E., and W.C. Fonteno. 1987. Effects of container geometry and media physical properties on air and water volumes in containers. Journal of Environmental Horticulture 5:180-182.

Bryan, D.L., M.A. Arnold, A. Volder, W.T. Watson, L. Lombardi, J.J. Sloan, and A.D. Cartwell. 2008. Overview of selected studies on the influence of planting depth on landscape establishment on container-grown trees. In: G.W. Watson, L. Costello, B. Scharenbroch, and E.F. Gilman (Eds.).The Landscape Below Ground III. Proceedings of International Workshop on Tree Root Development in Urban Soils. Morton Arboretum, Lisle, IL: International Society of Arboriculture, Champaign Illinois, U.S.

Chalker-Scott, L. 2007. Impact of mulches on landscape plants and the environment - a review. Journal of Environmental Horticulture 25:239-249.

Dahiya, R., J. Ingwersen, and T. Streck. 2007. The effect of mulching and tillage on the water and temperature regimes of a loess soil: Experimental findings and modeling. Soil and Tillage Research 96:52-63.

Demir, Z., O. Yildiz, and B. Toprak. 2009. Water retention ratios of mulching material consisting primarily of pine bark over different soil types. Pak. Journal of Botany 41:1851-1859.

Downer, J., and D. Hodel. 2001. The effects of mulching on establishment of Syagrus romanzoffiana (Cham.) Becc., Washingtonia robusta $\mathrm{H}$. Wendl. and Archontophoenix cunninghamiana ( $\mathrm{H}$. Wendl.) $\mathrm{H}$. Wendl. \& Drude in the landscape. Scientia Horticulturae 87:85-92.

Edwards, W.R.N. 1986. Precision weighing lysimetry for trees, using a simplified tared-balance design. Tree Physiology 1:127-144.

Erhart, E., and W. Hartl. 2003. Mulching with compost improves growth of blue spruce in Christmas tree plantations. European Journal of Soil Biology 39:149-156.

Ferrini, F., A. Fini, G. Amoroso, and P. Frangi. 2008. Mulching of ornamental trees: Effects on growth and physiology. Arboriculture \& Urban Forestry 34:157-162.

Gilman, E.F. 2001. Effect of nursery production method, irrigation, and inoculation with mycorrhizae-forming fungi on establishment of Quercus virginiana. Journal of Arboriculture 27:30-39.

Gilman, E.F., R.J. Black, and B. Dehgan. 1998. Irrigation volume and frequency and tree size affect establishment rate. Journal of Arboriculture 24:1-9.

Gilman, E.F., T.H. Yeager, and D. Weigle. 1996. Fertilizer, irrigation and root ball slicing affects Burford holly growth after planting. Journal of Environmental Horticulture 14:105-110.

Gilman, E.F., and J.C. Grabosky. 2004. Mulch and planting depth affect live oak (Quercus virginiana Mill.). Journal of Arboriculture 30:311-317.

Greenly, K.M., and D.A. Rakow. 1995. The effect of wood mulch type and depth on weed and tree growth and certain soil parameters. Journal of Arboriculture 21:225-232.

Hensley, D.L., R.E. McNiel, and R. Sundheim, 1988. Management influences on growth of transplanted Magnolia grandiflora. Journal of Arboriculture 14:204-207.

Hild, A.L., and D.L. Morgan. 1993. Mulch effects on crown growth of five southwestern shrub species. Journal of Environmental Horticulture 11:41-43.

Houle, G., and P. Babeux. 1994. Fertilizing and mulching influence on the performance of four native woody species suitable for revegetation in subarctic Quebec. Canadian Journal of Forest Research 24:2342-2349.

Johnson, G., and R. Hauer. 2000. A practitioner's guide to stem girdling roots of trees. <www.extension.umn.edu/distribution/naturalresources//DD7501.html>
Kraus, H.T. 1998. Effects of mulch on soil moisture and growth of desert willow. HortTechnology 8:588-590.

Litzow, M., and H. Pellet. 1983. Influence of mulch materials on growth of green ash. Journal of Arboriculture 9:7-12.

Medina, G., J. Altland, and D. Struve. 2005. Evapotranspiration rates of trees grown in pot-in-pot culture. Proceedings Southern Nursery Association Research Conference. 13:78-80.

Montague, T., C. McKenney, M. Maurer, and B. Winn. 2007. Influence of irrigation volume and mulch on establishment of select shrubs species. Arboriculture \& Urban Forestry 33:202-209.

Munir, A.D., N.M. Majid, I. Abdol, and G.S. Khan. 1998. Effects of mulching on the growth of interplanted Acacia mangium on sandy tin-tailings in Peninsular Malaysia. Lyallpur Akhbar 65:3.

Pearson, B., and M. Scheiber. 2006. Growth and aesthetic quality of Pentas as influenced by irrigation frequency. HortScience 42: 964-965.

Pruett, E. 1959. Mulch around newly planted trees can be detrimental. Station Note Central States Forest Experiment Station, No. 132.

Richards, D., M. Lane, and D.V. Beardsell. 1986. The influence of particle-size distribution in pinebark:sand:brown coal potting mixes on water supply, aeration and plant growth. Scientifica Horticulture 29:1-14.

Scharenbroch, B. 2009. A meta-analysis of studies published in Arboriculture and Urban Forestry relating to organic materials and impacts on soil, tree, and environmental properties. Arboriculture \& Urban Forestry 35:221-231.

Skroch, W.A., M.A. Powell, T.E. Bilderback, and P.H. Henry. 1992. Mulches: Durability, aesthetic value, weed control, and temperature. Journal of Environmental Horticulture 10:43-45.

Singer, C.K., and C.A. Martin. 2009. Effect of landscape mulches and drip irrigation on transplant establishment and growth of three North American desert native plants. Journal of Environmental Horticulture 27:166-170

Spooner, L.A. 1974. Two classroom exercises demonstrating the pattern of container soil water distribution. HortScience 9:152-153.

Smith, M.W., B.K.Carroll, and B.S. Cheary. 2000. Mulch improves pecan tree growth during orchard establishment. HortScience 35:192-195.

Steinberg, S.L., M.J. McFarland, and J.W. Worthington. 1990. Comparison of trunk and branch sap flow with canopy transpiration in pecan. Journal Experimental Botany 41:653-659.

Sun, D., G. Dickinson, and A. Bragg. 1994. The establishment of Eucalyptus camaldulensis on a tropical saline site in north Queensland, Australia. Agriculture, Ecosystems and Environment 48:1-8.

Unger, P.W., and J.J. Parker. 1976. Evaporation reduction from soil with wheat, sorghum, and cotton residues. Soil Science Society America Journal 40:938-942.

Watson, G.W., and G. Himelick. 1998. Principles and practice of planting trees and shrubs. International Society of Arboriculture, Champaign, Illinois, U.S.

Watson, G.W., and G. Kupkowski. 1991a. Effects of a deep layer of mulch on soil environment and tree root growth. Journal of Arboriculture 17:242-254.

Watson, G.W., and G. Kupkowski. 1991b. Soil moisture uptake by green ash trees after transplanting. Journal of Environmental Horticulture 9:227-230.

Wells, C., C.E.K.S. Townsend, J.D. Caldwell, D.L. Ham, M. Sherwood, and E.T. Smiley. 2006. Effects of planting depth on landscape tree survival and girdling root formation. Arboriculture \& Urban Forestry $32: 305-311$ 


\section{Edward F. Gilman (corresponding author) \\ Professor \\ Environmental Horticulture Department \\ University of Florida \\ egilman@ufl.edu}

Richard C. Beeson

Associate Professor

Mid-Florida Research and Education Center

University of Florida

\section{Dustin Meador}

Graduate Research Assistant

Environmental Horticulture Department

University of Florida

Résumé. Cette étude a été mise au point pour mesurer l'évaporation à partir d'un substrat de culture et d'un sol disposés dans des contenants de $360 \mathrm{~L}$ afin de simuler une motte mise en terre. Il n'y avait pas de différence d'évaporation, mesurée à l'aide d'un lysimètre, entre les contenants remplis de sol et recouverts de paillis et ceux sans paillis, et ce lors de chacune des trois journées consécutives qui suivaient une irrigation. Par contre, une plus grande évaporation survenait la première journée après l'irrigation avec les contenants remplis de substrat qui étaient recouverts de paillis de ceux qui étaient non recouverts de paillis. Les contenants remplis de substrat et non recouverts de paillis ont perdu plus d'eau par évaporation que ceux recouverts de paillis, et ce lors du second jour suivant l'irrigation. L'évaporation cumulative lors des deux premiers jours était identique pour les contenants remplis de substrat, et ce qu'ils soient ou non recouverts d'un paillis. L'évaporation cumulative lors de la troisième journée de sécheresse, après l'irrigation, était de $0,5 \mathrm{~L}$ plus élevée pour les contenants non recouverts de paillis en raison d'une évaporation plus élevée. Qu'il y ait ou non un paillis, seulement un litre environ s'évaporait à chaque jour de la surface des contenants remplis de sol ou de substrat durant des périodes consécutives de trois jours de sécheresse suivant l'irrigation. L'évaporation comptait pour environ $4 \%$ de la perte en eau de la motte pour les trois premiers jours suivants l'irrigation; en se basant sur des études similaires lorsqu'il y avait des arbres, le reste des $96 \%$ aurait été perdu via la transpiration. En raison des réductions mineures obtenues en évaporation, ainsi que des désavantages rapportées à propos de l'application de paillis près du tronc, les gestionnaires en aménagements paysagers pourraient considérer de changer les pratiques au niveau de l'application de paillis pour les arbres nouvellement plantés.

Zusammenfassung. Diese Studie wurde entwickelt, um die Verdunstung von substratgefüllten und mit Boden gefüllten Pflanzcontainern (360l) zu messen, um einen gepflanzten Wurzelballen zu simulieren. Es gab keine Differenz in irgendeiner fortlaufenden Drei-Tage-Periode nach der Bewässerung bei der Verdunstung zwischen gemulchten und ungemulchten Boden-gefüllten Lysimetern. In Gegenteil, mehr Evaporation trat am ersten Tag nach der Bewässerung aus den gemulchten, substratgefüllten Lysimetern auf, als aus den ungemulchten. Am zweiten Tag nach der Bewässerung verloren nicht gemulchte, substrat-gefüllte Lysimeter mehr Wasser durch Evaporation als gemulchte Lysimeter. Eine kumulative Evaporation während des zweiten Tages war für gemulchte und ungemulchte Substratbehandlungen identisch. Während des dritten Tages war die kumulative Evaporation nach der Bewässerung bei nichtgemulchten Lysimetern wegen der höheren Evaporation um 0,5 1 größer. $\mathrm{Ob}$ gemulcht oder nicht, nur ein Liter verdunstete täglich von der Oberfläche der substratgefülltten und mit Boden gefüllten Lysimeter während der fortlaufenden, dreitägigen, regen-freien Periode nach der Bewässerung. Die Evaporation stand für einen geschätzten Wasserverlust von 4 $\%$ aus den Wurzelballen in den ersten drei Tagen nach der Bewässerung. Basierend auf ähnlichen Studien mit diesen Bäumen würden die verbliebenen $96 \%$ durch Transpiration verloren werden. In Anbetracht der zu vernachlässigenden Reduktion der Evaporation und den berichteten Nachteilen der Mulchapplikation sollten die Landschaftsbauer eine Änderung der Mulchapplikation nach der Pflanzung erwägen.

Resumen. Este estudio fue diseñado para medir la evaporación de contenedores llenos con sustrato y con suelo $(360 \mathrm{~L})$ para simular una bola plantada con raíz. No hubo diferencia en la evaporación entre lisímetros con y sin mulch en cualquiera período consecutivo de riego de tres días. En contraste, ocurrió más evaporación en el primer día seco después del riego de lisímetros llenos con sustrato cubiertos con mulch que sin mulch. Los lisímetros no mulcheados perdieron más agua de evaporación que los lisímetros mulcheados en el segundo día después del riego. La evaporación acumulada a través del día dos fue idéntica para los tratamientos con sustratos mulcheados y no mulcheados. La evaporación acumulada a través del tercer día seco, después del riego, fue $0.5 \mathrm{~L}$ mayor en los lisímetros no mulcheados debido a la evaporación más alta. Mulcheados o no, solo cerca de un litro se evaporó diariamente de la superficie de los sustratos llenos con sustrato o suelo durante tres períodos libres consecutivos de lluvia después del riego. La evaporación se contabilizó para un estimado de $4 \%$ de pérdida de agua de la bola de raíz de los primeros tres días siguientes al riego. Basados en estudios similares con árboles presentes, el remanente $96 \%$ hubiese sido perdido a través de la traspiración. Dada la reducción menor en evaporación y las desventajas reportadas de aplicación de mulch cerca del tronco, los manejadores de paisajes podrían considerar cambiar las prácticas de aplicación de mulch para árboles recién plantados. 